\title{
Mechanical Properties and Antibacterial Activity of Cellulose Composite based Coconut Water with Addition of Glycerol, Chitosan, and Silver Nanoparticle
}

\author{
ELI ROHAETI ${ }^{1 *}$, ENDANG W LAKSONO FX ${ }^{2}$ and ANNA RAKHMAWATI ${ }^{3}$ \\ 1, 2Department of Chemistry Education, FMIPA, Yogyakarta State of University, \\ Jl. Colombo No. 1, Sleman DIY 55281 Indonesia. \\ ${ }^{3}$ Department of Biology Education, FMIPA, Yogyakarta State of University, \\ Jl. Colombo No. 1, Sleman DIY 55281 Indonesia. \\ ${ }^{*}$ Corresponding author E-mail: eli_rohaeti@uny.ac.id \\ http://dx.doi.org/10.13005/ojc/340320
}

(Received: January 03, 2018; Accepted: April 13, 2018)

\begin{abstract}
This study describes the mechanical properties and antibacterial activity of celluloses and their composites. The cellulose was prepared from coconut water fermented by Acetobacter xylinum. Cellulose was composited with chitosan and glycerol by immersion method and the addition of silver nanoparticles. Preparation of silver nanoparticles performed by chemical reduction of silver nitrate solution and polyvinyl alcohol as a stabilizer. UV-Vis spectroscopy was used to determine the formation of silver nanoparticles. Characterization of composites included observation of physical properties, mechanical properties, as well as antibacterial tests against S. aureus, E. coli, and C. albicans. The addition of glycerol can increase elongation at break of composites. The addition of glycerol and chitosan can decrease elongation at break and strength of the composites. The composite of cellulose - glycerol - chitosan - silver nanoparticles shows the highest antimicrobial activity against $S$. aureus on $24 \mathrm{~h}$ of incubation, whereas composite of cellulose - glycerol - silver nanoparticles shows the highest antimicrobial activity against $E$. coli and C. albicans.
\end{abstract}

Keywords: Coconut water, Antibacterial activity, Glycerol, Chitosan, Cellulose.

\section{INTRODUCTION}

Cellulose is an unbranched homopolysaccharide, elastic fibres, and insoluble in water. The cellulose is found in the protective cell wall, especially in the stems, branches and all woody parts of plant tissue, besides cellulose can be made with the help of Acetobacter xylinum 1 . In a liquid medium containing carbohydrates, this bacterium will produce acids of vinegar and a white coating on the surface of liquid media called nata.

One source of carbohydrates can be obtained from household waste, including coconut 
water. The utilization of coconut water has not been done optimally. In line with the increasing human need to make use of coconut water into functional materials with better economic value. When viewed further, waste coconut water has nutrients that can still be utilized. Coconut water contains $95.50 \%$ of water, $0.28 \%$ of potassium, $2.80 \%$ of total sugar, $0.80 \%$ of reducing sugar and $0.62 \%$ of ash. Coconut water also contains sucrose and vitamins $B$ complex including nicotinic acid, pantothenic acid, biotin, and folic acid. ${ }^{2}$ These nutrients can be used for the growth of Acetobacter xylinum, especially carbon and nitrogen content. Acetobacter xylinum can break down the sugar component in the coconut water medium and is capable of forming a polysaccharide known as cellulose.

The Acetobacter xylinum is capable of forming a cellulose-forming coating layer that can reach a few centimetres thick. ${ }^{3}$ Bacterial cellulose has the characteristic similar to human skin, so good for the treatment of burns on the human skin, especially in preventing infections caused by pathogenic microbes, but bacterial cellulose easily absorbs fluid (hygroscopic) so easily attacked by microbes. The bacterial cellulose can be modified by the addition of an ingredient into the culture medium to improve its antibacterial properties ${ }^{3}$. Modifications can be made through the addition of glycerol, chitosan, and silver nanoparticles. The addition of glycerol in the manufacture of bacterial cellulose in general aims to improve the mechanical properties of cellulose especially the elongation at break..$^{4,5}$ Chitosan in the form of a solution and gel, can be used as bacteriostatic, fungistatic, and coating material. The superior properties of bacterial cellulose and chitosan can be a composite material that interacts between the chitosan molecule part (glucosamine unit and $\mathrm{N}$-acetylglucosamine) in chitosan with the resulting cellulose chain. The combination of bacterial cellulose and chitosan can improve the antibacterial properties of cellulose. ${ }^{6}$ Modification of composite of bacterial cellulose - glycerol - chitosan can be done by adding nanometer - sized silver. Silver in the form of nanoparticles can interact among cell molecules contained in small organisms such as in bacteria or yeasts through electrostatic interactions.

Silver has a wide spectrum of antimicrobial activity that exhibits low toxicity to mammalian cells. Silver nanoparticles are generally smaller than $100 \mathrm{~nm}$ and contain as much as 20-15,000 atoms of silver. The silver nanoparticle has physical, chemical and biological properties. ${ }^{7}$ The antimicrobial activity of its silver and composite nanoparticles can be tested against Staphylococcus aureus and Escherichia coli, as well as Candida albicans yeast. Staphylococcus aureus is a major pathogen in humans. Almost everyone has experienced various $S$. aureus infections during their lifetime, such as food poisoning or mild skin infections, to incurable infections. ${ }^{8}$ Candida albicans includes endogenous or exogenous yeasts that are generally present in water, soil, and air, may cause opportunistic mycosis. As many as $70 \%$ of candida infections in humans are caused by Candida albicans, the rest are caused by C. tropicalis, C. parapsilosis, C. guillermondii, C. kruzei. $^{8}$

Based on the background, it is necessary to make various modifications to the cellulose from coconut water in inhibiting the growth of Staphylococcus aureus, Esherichia coli, and Candida albicans yeast. Modifications were made by adding glycerol, chitosan, and silver nanoparticles. Characterization includes the physical properties of cellulose and its composites, and the test of physical, mechanical, and antibacterial activities. This study aims to prepare a coconut water-based cellulose composite, test the mechanical properties, as well as antibacterial activity of cellulose and its composites.

\section{MATERIALS AND METHODS}

\section{Tools and materials}

The tools used in the study include UV-Vis spectrophotometer (Shimadzu 1601, Japan), tensile tester, oven (CIKA), autoclave (ALP Co., Ltd. KT-40 model), Bunsen burner, magnetic stirrer, hot plate, digital camera, sliding wheel, petri dish, micropipette, scales, three-neck flask, reflux set, and other glassware.

Materials used in the study include coconut waste (clear color, coconut scent, odorless, and non-greasy), chitosan, glycerol, starter of Acetobacter xylinum bacteria (PT Chem-Mix Pratama), yeast strains of Candida albicans ATCC 10231 (Pathology Laboratory in UGM), Staphylococcus aureus ATCC 25923 strain and Escherichia coli ATCC 32518 
(Microbiology Laboratory of Yogyakarta Health Center), $\mathrm{HCl}, \mathrm{NaOH}$, acetic acid, silver nitrate (E-Merck), sodium citrate (E-Merck), potato dextrose agar/PDA (Oxoid), Potato Dextrose Broth/ PDB medium (Oxoid), urea, granulated sugar, and alcohol.

\section{Preparation of cellulose and its composite}

As much as $100 \mathrm{~mL}$ of wastewater of coconut is poured into Erlenmeyer which has been equipped with a magnetic stirrer, then added 10 grams of sugar and $0.5 \mathrm{~g}$ of urea, and stirred until dissolved. The mixture was acidified with the addition of $25 \% \mathrm{CH}_{3} \mathrm{COOH}$ until $\mathrm{pH}=4$. The solution in the container was allowed to reach temperature $40-60{ }^{\circ} \mathrm{C}$ aseptically, then added $20 \mathrm{~mL}$ of Acetobacter xylinum. The culture was incubated for 7 days at room temperature. The formed layers were washed with aquadest to remove the residue of the culture medium. After purification of the pellicle by immersion in $3 \%$ of $\mathrm{NaOH}$ for $12 \mathrm{~h}$ by repeating 3 times the process to dissolve bacterial and pyrogenic cells, that bacterial cellulose samples were immersed in $3 \%$ of $\mathrm{HCl}$ solution to neutralize and washed again with aquadest. Furthermore, drying of bacterial cellulose samples at $70-80^{\circ} \mathrm{C}$ for \pm 120 min. to obtain cellulose product (C).

Furthermore, the composite of cellulose - glycerol (CG) was prepared by pouring $100 \mathrm{~mL}$ of waste water into Erlenmeyer then adding 10 $\mathrm{g}$ of sugar and $0.5 \mathrm{~g}$ of urea, and stirring until dissolved. The mixture was acidified by adding $25 \%$ of $\mathrm{CH}_{3} \mathrm{COOH}$ until $\mathrm{pH}=4$. Then $0.5 \mathrm{~g}(1.2 \mathrm{~mL})$ of glycerol as a plasticizer, was added and stirred while heated. It was then poured hot in a sterilized and closed fermented container. The solution in the container was allowed to reach $40-60^{\circ} \mathrm{C}$ aseptically, then $20 \mathrm{~mL}$ of Acetobacter xylinum was added. The culture was incubated for 12 days at room temperature. The formed layers were washed with aquabidest to remove the residue of the culture medium. After purification of the pellicle by immersion in $3 \%$ of $\mathrm{NaOH}$ for $12 \mathrm{~h}$ by repeating 3 times the process to dissolve bacterial and pyrogenic cells, the solution was then filtered to remove the dissolved material. After that the pellicle was soaked in 3\% of $\mathrm{HCl}$ solution to neutralize and be washed again with aquadest. Furthermore, drying of the samples at $70-80^{\circ} \mathrm{C}$ for \pm 120 minutes.
Furthermore, the composite of cellulose - glycerol - chitosan (CGCh) was produced by immersing the CG composite in $2 \%$ of chitosan solution until the solution of chitosan was absorbed. Then the sample was washed with $500 \mathrm{~mL}$ of $1 \mathrm{M}$ $\mathrm{NaOH}$ and aquadest to remove the remaining alkali and neutralize the sample. The sample is then dried at a temperature between $50-65^{\circ} \mathrm{C}$ for 24 hours. The cellulose and its composite were characterized their physical and mechanical properties.

\section{Preparation of silver nanoparticle}

The silver nanoparticles were prepared by refluxing $100 \mathrm{~mL}$ of a $1 \times 10^{-3} \mathrm{M}$ silver nitrate solution by streaming nitrogen gas at a temperature of less than $90^{\circ} \mathrm{C}$ while stirring. Then add drops of sodium citrate at a temperature of about $80-90^{\circ} \mathrm{C}$ to a pale yellow solution. The heating and gas flow of nitrogen was stopped while stirring was carried out until the room temperature reached. The resulting colloid was characterized by a UV-Vis spectrophotometer.

\section{Application of silver nanoparticle to cellulose and its composite}

The application of silver nanoparticles to cellulose, cellulose-glycerol composites, and cellulose - glycerol-chitosan composites was performed by introducing cellulose and its composite into colloidal silver nanoparticles until submerged and then shakered for $60 \mathrm{~min}$. at $145 \mathrm{rpm}$. Table. 1 shows the variation of cellulose and its composite were prepared in this work

\section{Test of antibacterial activity}

The test microbes were cultured on NB media for Staphylococcus aureus and PDB media

Table 1: Variation of cellulose and its composite

\begin{tabular}{|c|c|c|}
\hline No. & $\begin{array}{l}\text { Code } \\
\text { of samples }\end{array}$ & Component \\
\hline 1 & C & Cellulose \\
\hline 2 & CG & Cellulose and glycerol \\
\hline 3 & CGCh & Cellulose, glycerol, and chitosan \\
\hline 4 & $\mathrm{CN}$ & Cellulose and silver nanoparticle \\
\hline 5 & CGN & $\begin{array}{l}\text { Cellulose, glycerol, and silver } \\
\text { nanoparticle }\end{array}$ \\
\hline 6 & CGChN & $\begin{array}{l}\text { Cellulose, glycerol, chitosan and } \\
\text { silver nanoparticle }\end{array}$ \\
\hline
\end{tabular}


for Candida albicans for $24 \mathrm{~h}$ at $37^{\circ} \mathrm{C}$. The turbidity of test bacteria using a scale of turbidity (OD) of 1 or Brown III is $108 \mathrm{CFU} / \mathrm{mL}$. As much as $15 \mathrm{~mL}$ of NA medium with a temperature of $\pm 50^{\circ} \mathrm{C}$ was poured into petridish. After the media solidified, the Staphylococcus aureus was poured and flattened in a way evenly applied. Then a cellulose sample was planted on prepared media and incubated for $2 \times 24$ hours at $37^{\circ} \mathrm{C}$. Clear zones indicated a growth barrier of microorganisms by antimicrobial agents on the surface of the agar medium. ${ }^{9}$

As much as $15 \mathrm{~mL}$ of PDA media with temperature $\pm 50^{\circ} \mathrm{C}$ was poured into a petridish. After the media solidified, the Candida albicans was poured and flattened in an evenly applied manner and the samples were planted in a prepared media and incubated for $2 \times 24 \mathrm{~h}$ at $37^{\circ} \mathrm{C}$. The diameter of inhibition zone was measured by 3 times at different positions, the measurement was taken perpendicularly from the three zones of the clear zone side through the sample diameter. Data of inhibition zone was analyzed using a statistic analysis One Way ANOVA with significance level $(P<0.05)$. If there was a difference, then proceed with an analysis of Duncan Multi-Range Test (DMRT).

\section{RESULTS AND DISCUSSION}

\section{Physical properties of cellulose and its composite}

The physical properties of cellulose and its composites are shown in Table. 2. The addition of glycerol and chitosan to cellulose causes a decrease in the resultant wet mass of the composite, indicating that the addition of glycerol and chitosan affects the formation of the pellicle. Glycerol has hydrophilic properties so that the water content in the CG sample increases and the resulting water content becomes high. Decreasing of wet mass of composites due to addition of glycerol and chitosan, this suggests the possibility of interaction between the -OH group of the cellulose with $-\mathrm{NH}$ group of the chitosan and $-\mathrm{OH}$ group of the glycerol producing a lower-mass molecule. The CGCh composite has a higher dry yield than $C$ and $C G$. The cellulose is a very hygroscopic material and attracts water through hydrogen interactions. ${ }^{10}$ This is consistent with the results in the $C$ and $C G$ groups having a smaller dry mass than CGCh. The event can be explained because the added chitosan is able to enter the cellulose pores and coat the cellulose surface so that the water in the environment can not enter. Observation of other physical properties of colour change occurs in CGCh, this is influenced by chitosan added has a brownish-yellow colour and has a strong acid odour. Based on the physical properties of cellulose samples and their variations, it can be seen that all samples are transparent. Organoleptic observation of color changes in CGCh, the addition of chitosan, causing the color to be brownish-yellow, it is because chitosan has a brownish yellow color when dissolved in acetic acid and can cause acid odor.

\section{Characteristic of silver nanoparticle}

Figure 1 shows the UV-Vis spectrum of the of silver nanoparticles. The silver nanoparticles successfully prepared from $\mathrm{AgNO}_{3}$ are shown by an absorption peak of 0.954 at a wavelength of 421.80 $\mathrm{nm}$. The size of the established silver nanoparticles can be predicted based on the $\lambda$ max value, the larger the particle size of the silver, the absorption peak will shift towards a larger wavelength in the $395-450 \mathrm{~nm}$ range and the wider peak. These results indicate that the preparation of silver nanoparticles is perfect. Based on the results of the nanoparticle

Table 2: Physical properties of cellulose and its composites

\begin{tabular}{lccc}
\hline Parameter & $\mathrm{C}$ & $\mathrm{CG}$ & CGCh \\
\hline Wet mass & $100.44 \mathrm{~g}$ & $106.33 \mathrm{~g}$ & $94.70 \mathrm{~g}$ \\
Dry mass & $1.40 \mathrm{~g}$ & $1.49 \mathrm{~g}$ & $3.56 \mathrm{~g}$ \\
$\%$ wet yield & $83.7 \%$ & $88.60 \%$ & $78.91 \%$ \\
$\%$ dry yield & $1.39 \%$ & $1.40 \%$ & $3.75 \%$ \\
Transparency & Transparent & Transparent & Transparent \\
Colour & White & Yellow & Brownish yellow \\
Elasticity & Elastic & Elastic & Less elastic \\
Odour & Odourless & Odourless & The sour-smelling \\
\hline
\end{tabular}


size test and compared with the previous work ${ }^{11}$, it was demonstrated that the silver nanoparticles were

produced by the reduction of silver nitrate solution with a particle size of $60-80 \mathrm{~nm}$.

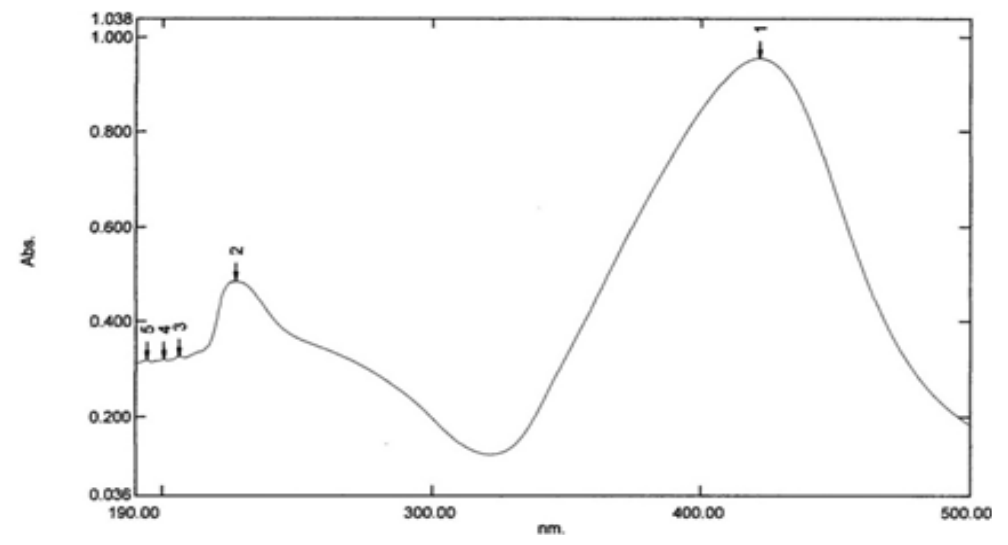

Fig. 1. Uv-Vis spectrum of silver nanoparticle

\section{Mechanical properties of cellulose and its composites}

The mechanical properties of the cellulose and composite samples after addition of the silver nanoparticles are shown in Table 3. The addition of glycerol to cellulose enhances the extent of cellulosic breakdown. The addition of glycerol to increase the number of oxygen atoms that have free electron pairs leads to increased flexibility of the group, the ability of the polymer undergoes an increasing extension. ${ }^{10,12}$ Glycerol acts as an internal plasticizer that can increase the elongation at break of the polymer. ${ }^{13}$ The decrease in break strength in CGN and CGChN samples due to the properties of glycerol as the plasticizer to make the rigidity of the material decreases, The mechanical properties of cellulose can be explained by the intensity of the functional groups contained in each cellulose. The cellulose has many $\mathrm{OH}$ groups, can increase flexible groups, so the elasticity of the polymer increases.

Table 3: Mechanical properties of cellulose and its composites with addition silver nanoparticle

\begin{tabular}{lccc}
\hline No. & Type of sample & $\begin{array}{c}\text { Parameter of mechanical properties } \\
\text { Strength at break (MPa) }\end{array}$ & Elongation at break (\%) \\
\hline 1. & CN & 40.67 & 19.81 \\
2. & CGN & 31.75 & 30.65 \\
3. & CGChN & 3.74 & 2.13 \\
\hline
\end{tabular}

The addition of chitosan in the CGChN decreases the value of strength at break and elongation, this may be due to the decreasing of the intermolecular bonding distance (Li et al., 2015) ${ }^{14}$ thereby reducing the mobility of CGChN molecules. The decreasing strength at break in CGChN could be caused by crystallinity in composite by the addition of amorphous chitosan. ${ }^{5}$ The addition of glycerol and chitosan to the CGChN composite decreases the elongation at break, this may be due to the intermolecular bonding of cellulose. The addition of glycerol and chitosan can increase the amount of hydrogen bonding in CGChNs so that molecular mobility of those decreases. In addition, the amorphous chitosan and the presence of hydrogen bonds between the $-\mathrm{OH}$ group of glycerol and the $-\mathrm{NH}_{2}$ group of chitosan with the $-\mathrm{OH}$ group of cellulose and the intramolecular bond between the chitosan molecules ${ }^{14}$ caused decreasing the value of elongation at break of the CGChN composite.

Antibacterial activity of cellulose and its composites Analysis of antimicrobial activity from $\mathrm{CN}$, CGN, and CGChN samples against test microbes 
i.e. Staphylococcus aureus, Escherichia coli, and Candida albicans for $24 \mathrm{~h}$ was shown in Table 4. The results showed that all samples of composites by addition silver nanoparticles have an antimicrobial effect.

Table 4: Diameter of inhibition zone of cellulose and its composites against

Staphylococcus aureus, Escherichia coli, and Candida albicans for $\mathbf{2 4}$ hours

No Cellulose Diameter of inhibition zone $(\mathrm{mm})$ S.aureus E.coli C.albicans

\begin{tabular}{lclll}
\hline 1. & CN & 1.750 & 0.830 & 1.550 \\
2. & CGN & 1.910 & 1.660 & 2.290 \\
3. & CGChN & 2.320 & 1.330 & 1.620 \\
\hline
\end{tabular}

The CGChN samples show the highest diameter of the zones against $S$. aureus compared to other composites and the CGN samples show the highest clear zone against $E$. coli and $C$. albicans compared to other composite samples. This means that the CGChN sample has an antibacterial activity or the ability to inhibit $S$. aureus better than the $\mathrm{CN}$ and CGN. This is probably due to the presence of bonds between the silver nanoparticles and the $-\mathrm{OH}$ group of glycerol and the bonds between the silver nanoparticles and the $-\mathrm{NH}_{2}$ groups of chitosan. The CGChN contains more $-\mathrm{OH}$ and $-\mathrm{NH}_{2}$ groups than $\mathrm{CN}$ and $\mathrm{CGN}$ samples. The antibacterial properties become larger by the increasing number of interactions that occur between the silver nanoparticles with those clusters and the presence of free $-\mathrm{OH}$ groups as well as $-\mathrm{NH}$ which can interact with the microbial cell wall components. The interaction between cellulose with glycerol and chitosan is presented in Fig. 2 . In addition, the antibacterial activity of CGChN can be caused by the ability of chitosan as a bactericidal agent in killing bacteria $^{15,16,17}$.

The CGN sample shows the highest antibacterial activity against E.coli and C. albicans compared to other composite samples. The addition of glycerol to cellulose increases the number of oxygen atoms that have free electron pairs so that the interaction with the silver nanoparticles becomes larger. Fig. 3 shows the interaction between cellulose and glycerol. The composite of cellulose - glycerol has free $-\mathrm{OH}$ more to bind to the silver nanoparticles so that the activity against bacteria is higher. The increase of flexible groups in composite causes silver nanoparticles to bind more easily. In addition, glycerol has antibacterial properties. ${ }^{17,18,19}$

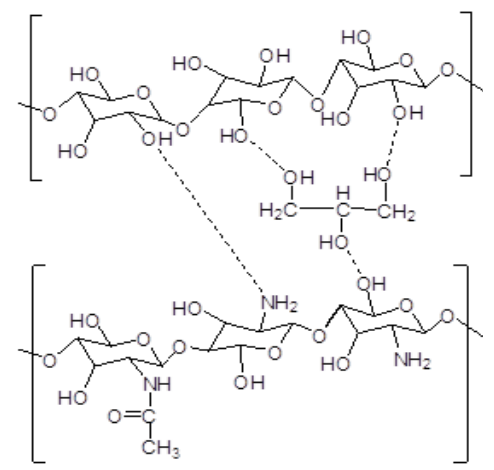

Fig. 2. Interaction among cellulose, glycerol, and chitosan

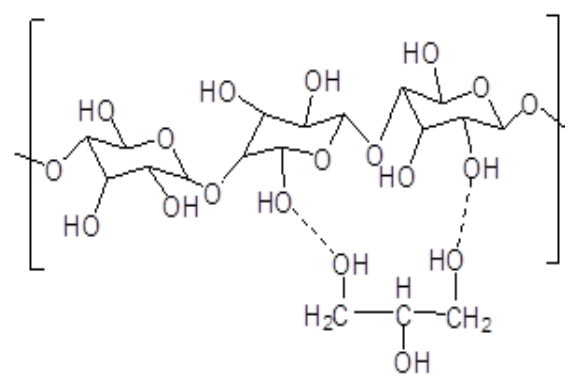

Fig. 3. Interaction between cellulose and glycerol

Cellulose has fewer $\mathrm{OH}$ groups than the other samples. This is due to the regular (crystalline) cellulose structures that make it difficult for the silver nanoparticles to bind to functional group of the cellulose, while the addition of chitosan results in the more amorphous nature of cellulose because of its decreased crystallinity value. ${ }^{5}$ This facilitates the electrostatic interaction of the silver nanoparticles attacking the functional groups in cellulose.

Figure 4. shows the antibacterial activity of CGChN, CGN, CN, and silver nanoparticle (N) against Staphylococcus aureus at every 6 hours. The largest inhibitory zone diameter in the CGN sample was followed by $\mathrm{CN}$ and $\mathrm{CGChN}$. The low ability of CGChN to inhibit the activity of 
Staphylococcus aureus is caused by the interaction between chitosan and silver nanoparticle causing the decrease of intramolecular hydrogen bond strength and chitosan intermolecular after the existence of nanoparticle, and the formation of hydrogen bond between chitosan and glycerol. This was possible because the interaction of $\mathrm{Ag}$ with the $-\mathrm{NH}_{2}{ }^{20}$ and -OH groups causes a decrease in inhibitory power to the Staphylococcus aureus.

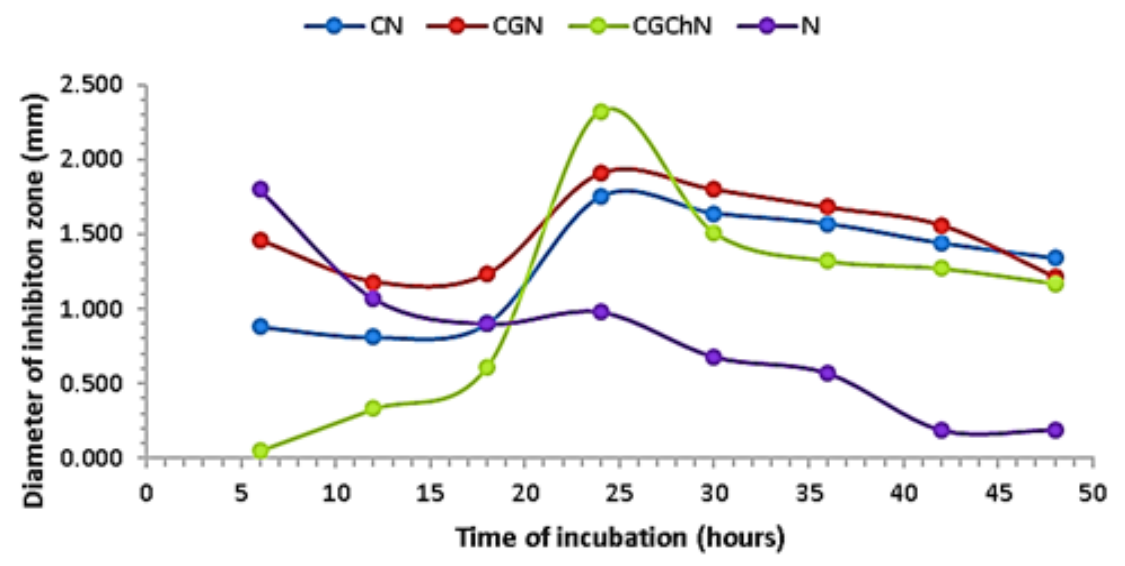

Fig. 4. Diameter of inhibition zone of cellulose and its composites (CN, CGN, CGChN, N) against S.aureus

There is a difference in inhibitory zone diameter of all cellulose samples on the growth of Staphylococcus aureus. All cellulose samples coated silver nanoparticles show higher antibacterial activity than silver nanoparticles, except CGChN samples in 6 to $18 \mathrm{~h}$ of incubation. The CGChN samples show the highest antibacterial activity compared to other samples at incubation for 24 hours. This can be explained because in $24 \mathrm{~h}$ incubation, there is an interaction between silver nanoparticles with chitosan which can increase antibacterial activity ${ }^{12}$ also because chitosan shows bactericidal properties. ${ }^{16}$ In accordance with the previous results ${ }^{14}$ that modification of silver nanoparticles with chitosan/Ag/ $\mathrm{ZnO}$ can improve the ability of Ag nanoparticles as inhibiting bacterial activity. The inhibition mechanism of chitosan against Staphylococcus aureus is due to the positive charge of chitosan derived from an ionic-bound amine $\left(\mathrm{NH}_{3}^{+}\right)$group that is reactive to the surface of the bacterial cell membrane, this will cause the entire surface of the $S$. aureus cell membrane to be coated by chitosan, so that $S$. aureus can not contact with the outer environment of the cell. Furthermore, ionic bonds formed between chitosan and $S$. aureus cell membrane will disrupt the permeability of membranes and chitosan able to penetrate the membrane of $S$. aureus cells. Chitosan is brought into the intercellular space of $S$. aureus and binds to DNA of $S$. aureus because of its strong affinity with DNA of $S$. aureus, then interferes with mRNA and protein synthesis. Then there will be disruption of cell function, followed by leakage of cell protein because chitosan meet the intercellular space then cell protein depressed to intercellular space, followed by lysis of $S$. aureus and then S. aureus death. ${ }^{21}$

The ability of antimicrobial of each sample against $S$. aureus has difference and the CGN compocite has a larger inhibitory compared with other cellulose. This can be explained because the silver nanoparticles from CGN can interact with Staphylococcus aureus through the bacterial cell wall. This interaction causes the changing of permeability of the Staphylococcus aureus cell wall. The permeability of the Staphylococcus aureus cell wall to be disrupted. During the diffusion process, the silver nanoparticles move closer to the bacterial cell membrane and penetrate into the bacteria ${ }^{22}$. Bacteria membranes contain proteins with sulfur compounds as their main component. ${ }^{23}$ The interaction involves the interaction of nanoparticle with biological macromolecules, by releasing heavy metal ions that react with thiol (-SH) groups on surface proteins. Monovalent silver ions $\left(\mathrm{Ag}^{+}\right)$can replace hydrogen cations $\left(\mathrm{H}^{+}\right)$from the thiol sulfhidryl group, resulting 
in S-Ag groups and inactivating proteins, decreased membrane permeability, and ultimately leading to cellular death. ${ }^{7}$

Figure 5. shows the greatest antibacterial activity in inhibiting the growth of Candida albicans is CGN sample followed by CGChN and CN. The emergence of the highest inhibition zones at the 6 th hour of each sample can be due to the 6th hour is an effective time for silver nanoparticles in inhibiting Candida albicans. Inhibitory zones begin to appear at the beginning of the first $6 \mathrm{~h}$ to the end of the 48 hours. This is because the ability of silver nanoparticles interferes with the integrity of Candida albicans cell plasma membranes. There were several intracellular components released during disruption of the plasma membrane by silver nanoparticles, so membrane permeability was impaired and lead to leakage of ions and other materials, thus possibly causing Candida albicans lysis and it death. ${ }^{17}$

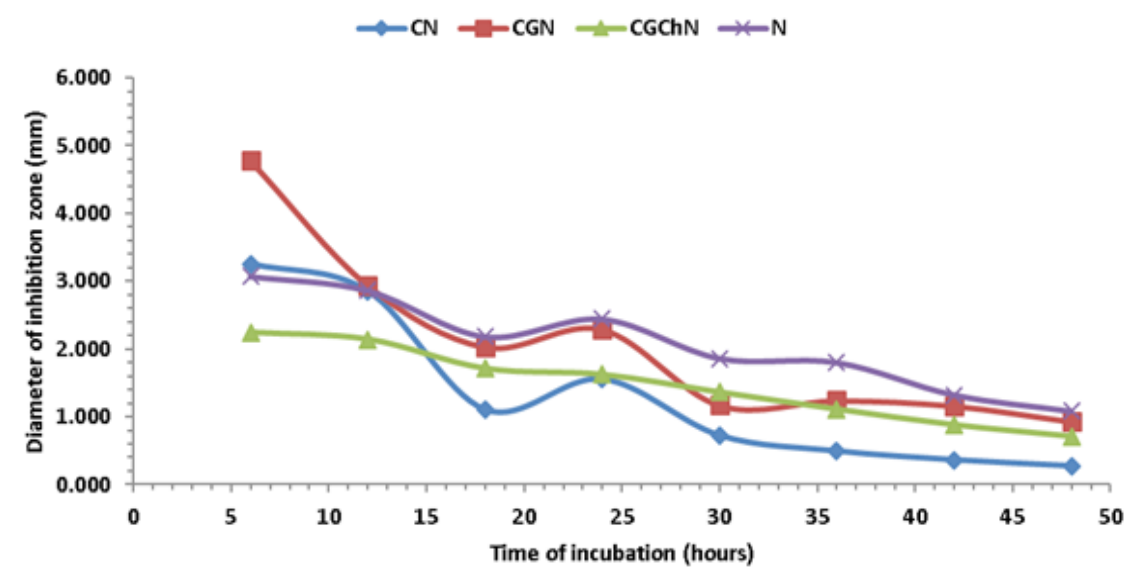

Fig. 5. Diameter of inhibition zone of cellulose and its composites (CN, CGN, CGChN, N) against Candida albicans

The effect of silver nanoparticles on bacteria varied with the concentration of silver nanoparticles and the time of exposure. ${ }^{14}$ DNA of Candida albicans becomes thick after exposure for $6 \mathrm{~h}$ and after $12 \mathrm{~h}$ of exposure, cellular content releases due to cell wall damages. It is seen that at the $12 \mathrm{~h}$ the average of the inhibition zone diameter of CN, CGN, CGChN, and silver nanoparticles decreases.

The antibacterial activity of cellulose and composite in inhibiting the growth of $S$. aureus and Candida albicans tends to increase again at $24 \mathrm{~h}$ and down again at the 30th hours. The antibacterial activity of cellulose and its composites against the growth of $S$. aureus and $C$. albicans microbes in incubation for $30 \mathrm{~h}$ shows a decrease in the diameter of the inhibition zone and the presence of spots of $S$. aureus and $C$. albicans around the test sample. Thus incubation longer than $48 \mathrm{~h}$ will not significantly effect the reduction of antibacterial activity. Cellulose and its composites are able to act as bactericidal rather than bacteriostatic. The bactericidal is the ability of a compound to kill bacteria and bacteria will not have the ability to regenerate even if the compound is removed.

The inhibition of cellulose and its composites against $S$. aureus showed no significant difference with significance $(P>0.005)$, indicating that cellulose (CN, CGN, and CGChN) did not have different capabilities in inhibiting $S$. aureus, whereas cellulose and its composites against Candida albicans showed significantly different results $(P<0.005)$, proving that each sample (CN, CGN, and CGChN) has the ability to inhibit Candida albicans significantly. Staphylococcus aureus is a pathogenical bacteria, having a single plasma membrane surrounded by a thick cell wall of peptidoglycan. About $90 \%$ of the cell wall is composed of peptidoglycan while the rest is a teicoic acid molecule. On the other hand, Candida albicans has a complex cell wall structure with a thickness of 100 to $400 \mathrm{~nm}$. The primary composition consists of glucan, mannan, and chitin. Thus, cellulose and its composites are more susceptible to diffusion in Candida albicans because they are largely composed of chemical compounds. 
The mechanism of interaction between chitosan and yeast shows that chitosan can withstand yeast growth by the destruction of biological membranes. The antimicrobial mechanism of chitosan through the interaction between the positive charge of the $\mathrm{NH}_{3}{ }^{+}$group of the glucosamine unit on chitosan and the negative charge on the yeast cell membrane resulting in electrostatic interaction. A change of permeability in the yeast membrane wall can decrease internal osmotic balance to inhibit yeast growth and peptidoglycan hydrolysis of the yeast wall resulted in the loss of intracellular electrolytes, proteins, nucleic acids, and glucose in yeast. ${ }^{16,24}$

\section{CONCLUSION}

Cellulose from coconut water was successfully modified by the addition of glycerol, chitosan, and silver nanoparticles. The addition of glycerol and chitosan decreased wet mass and wet yield but increased dry mass and dry yield of composites. The addition of glycerol may increase the elongation at break, but decrease the strength at break. The addition of glycerol and chitosan decreases the elongation at break and strength at break of the composite. Cellulose and cellulose composites show antibacterial activity against S.aureus, E. coli, and C. albicans. Composite of cellulose - glycerol - chitosan - silver nanoparticles shows the highest antimicrobial activity in inhibiting $S$. aureus at $24 \mathrm{~h}$ of incubation, whereas the composite of cellulose - glycerol - silver nanoparticles shows the highest antimicrobial activity in inhibiting the growth of E. coli and C. albicans.

\section{ACKNOWLEDGEMENT}

Thanks to Ministry of Research, Technology, and Higher Education of the Republic Indonesia for the finance support by Incentive of SINas Research 2014.

\section{REFERENCES}

1. Goh, W.N.; Rosma, A.; Kaur, B.; Fazilah, A.; Karim, A.A.; Bhat, R. Int. Food Res. J., 2002, 19(1), 153-158.

2. Lilies, S. Peluang Usaha Nata de Coco. Kanisius, Yogyakarta, Indonesia. 2004.

3. Ciechañska, D.; Wietecha, J.; KaŸmierczak, D.; Kazimierczak, J. Fibres Text. East. Eur., 2010, 18(5), 98-104.

4. Zhang, H.; Deng, L.; Yang, M.; Min, S.; Yang, L.; Zhu, L. Int. J. Mol. Sci. 2011, 12(1), 3170-3181.

5. Torres, F. G.; Troncoso, O. P.; Torres, C.; Diaz, D.; Amaya, E. Int. J. Biol. Macromol. doi:10.1016/j.jibiomac.2011.01.026, 2011, 48(1), 603-606.

6. Maneerung, T.; Tokura, S.; Rujiravanit, R. Carbohyd. Polym., 2007, 72(1), 1-9.

7. Haryono, A. and Harmami, S. B. Jurnal Kimia Indonesia., 2010, 5(1), 1-6.

8. Jawetz, E.; Melnick, J.; Adelberg, E. Mikrobiologi Kedokteran, , Bagian Mikrobiologi FK UNAIR, edisi 1, Salemba Medika, Jakarta., 2005.

9. Kumar, V.; Jolivalt, C.; Pulpytel, J.; Jafari, R.; Arefi-Khonsari, F. J. Biomed. Mat. Res. A., 2012, OOA(00), 1-12.

10. Rechia, L.M.; Morona, J.B.J.; Zepon, K.M.; Soldi, V.; Kanis, L.A. Braz. J. Pharma. Sci., Available at: http://dx.doi.org/10.1590/S198482502010000300012, 2010, 46(3).

11. Rosyita, D. Undergraduate Thesis. Universitas Indonesia, Jakarta, Indonesia. 2013.

12. Lin, W.C.; Lien, C.C.; Yeh, H.J.; Yu, C.M.; Hsu, S.H. Carbohyd. Polym., 2013, 94(1),
603-611.

13. Yunos, M. B. Z. and Rahman, W. A. J. Appl. Sci., 2011, 11(13), 2456-2459.

14. Li, X.; Yang, M.; Shi, X.; Chu, X.; Chen, L.;Wu, Q.; Wang, Y. Phys. E: Low-dimensional Sys. Nanostruct., 2015, 69(1), 237-242.

15. Tavaria, F. K.; Soares, J. C.; Reis, I. L.; Paulo, M. H.; Malcata, F. X.; Pintado, M. E. J. Appl. Microbiol., 2012, 112(5), 1034-1041.

16. Tikhonov, V. E.; Stepnova, E. A.; Babak, V. G. Carbohydrat. Polym., 2006, 64(1), 66-72 .

17. Kim, K.W.; Min, B. J.; Kim, Y.T.; Kimmel, R. M.; Cooksey, K.; Park, S. I. Food Sci. Technol., 2011, 44(2), 565-569.

18. Singh, B. R. Medicine., 2013, 1, 1-3.

19. Saegeman, V. S. M.; Ectors, N. L.; Lismont, D.; Verduyckt, B.; Verhaegen, J. Burns., 2008, 34, 205-211.

20. Uznanski, P.; Zakrzewska, J.; Favier, F.; Kazmierski, S.; Bryszewska, E. J. Nanopart. Res., 2017, 19(3), 121 doi: 10.1007/s11051017-3827-5.

21. Jin, J-C.; Xu, Z-Q; Dong, P.; Lan, J-Y.; Jiang, F-L.; Liu, Yi. 2015 doi:10.1016/j. carbon.2015.05.084.

22. Mahendra, R.; Yadav, A.; Gade, A. Biotechnol. Adv., 2009, 27, $76-83$.

23. Handaya, A.; Joddy, A. L.; Haryono, A. Final Report. 2010, Sinergi DIKTI - LIPI, Indonesia.

24. Titik, I.; Siswi, S.; Harini, S. Proc. Incentive Res. 2013, KNRT, Jakarta, Indonesia. 